\title{
Racial Differences in Pain, Nutrition, and Oxidative Stress
}

\author{
Larissa J. Strath · Robert E. Sorge (D)
}

Received: September 2, 2021 / Accepted: January 21, 2022 / Published online: February 1, 2022

(c) The Author(s) 2022

\begin{abstract}
Investigating the disproportionate rates of chronic pain and their related comorbidities between Black and non-Hispanic White (White) individuals is a growing area of interest, both in the healthcare community and in general society. Researchers have identified racial differences in chronic pain prevalence and severity, but still very little is known about the mechanisms underlying them. Current explanations for these differences have primarily focused on socioeconomic status and unequal healthcare between races as causal factors. Whereas these factors are informative, a racial gap still exists between Black and White individuals when these factors are controlled for. One potential cause of this racial gap in chronic pain is the differences in nutrition and dietary intake between groups. Certain foods play a key role in the inflammatory and oxidative stress pathways in the human body and could potentially influence the severity of the pain experience. Here, we review the previous literature on the surrounding topics and propose a potential mechanism to explain racial differences in the
\end{abstract}

L. J. Strath · R. E. Sorge $(\bowtie)$

Department of Psychology, The University of

Alabama at Birmingham, 1300 University Blvd,

Birmingham, AL 35294, USA

e-mail: rsorge@uab.edu chronic pain population, based on established racial differences in diet and oxidative stress.

Keywords: Race; Diet; Pain; Inflammation; Oxidative stress

\section{Key Summary Points}

There are identified racial differences in pain experience.

Dietary intake and metabolic responses may differ between racial groups.

Specific foods and food components have direct and indirect effects on inflammation.

Oxidative stress as a result of different diet may be the mechanism underlying racial differences in pain.

\section{INTRODUCTION}

The prevalence of chronic illness is increasing with an aging population, leading to higher healthcare costs and increasing morbidity for these populations [1]. As a consequence, there is a growing interest in chronic pain [2, 3], a 
disease state that has tremendous impact on quality of life, health, and socioeconomic conditions $[4,5]$. Chronic pain is defined as any pain that is recurrent or long lasting-typically 6 months or more [6]. It is a unique experience, with complex biopsychosocial pathology, and has very burdensome effects on both physical and mental health. While chronic pain can, at times, develop from an initial injury or insult, it is not simply an extension of acute pain and requires different diagnostic and management strategies [7]. Attempts to treat this disease state have primarily relied on pain-masking pharmaceuticals. Analgesics have demonstrated efficacy in relieving pain, but the healthcare community is now facing an epidemic as more and more people per year die due to overdose or complications with these drugs, particularly the opioids [8-11]. This social crisis has prompted providers and researchers alike to investigate whether there are treatments that exist that relieve pain but do not have the costly side effects of current therapies. Unfortunately, the burden associated with pain does not fall equally on all groups.

To alleviate differences in chronic pain, the underlying mechanisms require elucidation. In addition to racial differences, there are recognized differences in pain that are related to sex and age. There are significant differences in pain threshold and tolerance between the males and females [12-14], with females reporting increased sensitivity and greater likelihood of developing a chronic pain disorder [15]. Older individuals are also at a higher risk for development and increased severity of painful disorders [16]. There are multiple explanations for these phenomena: genetic and hormonal differences in brain neurochemistry, immune system differences, social and cultural expectations of societal roles, and differences in coping strategies [17].

Of particular importance to this review is the disparity between races with respect to pain. In general, race is derived from biological dispositions; however, it is important to note that there are both biological and social components of race that play pivotal roles in the lives of individuals. Early medical research failed to include Black individuals in experiments [18], and it was not until the shift in civil rights that racial differences in pain were first documented by Chapman and Jones in 1944 [19]. Since that time, racial disparities have been documented in many works, revealing that Black individuals disproportionately carry the burden of chronic pain in comparison to their non-Hispanic White (White) counterparts [20-24]. Although the underlying mechanisms for the disparity are unclear, the fact that clinical pain is more prevalent in the Black population is well beyond doubt.

Racial differences in pain are thought to exist for many reasons: genetic predispositions [25]; differences in psychosocial and cultural factors between the two groups [26]; reported differences in coping strategies between races [27]; disparities in healthcare systems and providers [4]; and finally, differences in diet [28]. We [29-31] and others [32-36] have shown that diets varying in nutritional quality affect the outcome of the pain experience. For example, a high-carbohydrate diet can result in systemic inflammation, immune cell activation, and prolonged recovery from injury [29, 37]. On the other hand, a diet low in carbohydrates can promote recovery from injury [29] and reduce daily and evoked pain [38]. Knowing that nutritional quality affects pain and that there are reported differences in dietary consumption of food [39] and documented differences in inflammatory processes (including oxidative stress) between racial groups [40], it is possible that the differences in the diet between Black and White individuals is a major contributing factor to the differences seen in the rates of chronic pain. This article is based on previously conducted studies and does not contain any new studies with human participants or animals performed by any of the authors.

\section{RACIAL DIFFERENCES IN PAIN}

Differences in pain between racial groups have been documented in clinical and experimental research [41, 42] and overwhelmingly report that Black individuals are indeed at an increased risk for developing a chronic pain condition, consistently reporting higher incidence rates 
and greater burden [43]. Common types of pain conditions are outlined below.

\section{Emergency Medicine and Postoperative Pain}

Pain is one of the most common complaints seen in emergency departments (EDs) across the United States [44]. Over the past two decades, several reports have documented that Black individuals are at risk for undertreatment of pain compared to White individuals. Even when medical conditions are equated, Black individuals are less likely to receive adequate pain medication [45]. It should be noted that these data are often based on ED and postoperative analgesic administration to patients, as opposed to functional pain measures. Using analgesic administration as the primary measure can be problematic, as it is possible that internal bias of the provider may directly affect the amount of medication administered to the patient. Many investigations, including the National Hospital Ambulatory Medical Care Survey (NHAMCS), report evidence suggesting racial differences in pain medication administration by physicians in the ED for specific painful conditions [46-49], while others have reported no differences [50-54]. In studies examining pain after surgery, Black individuals report more pain and pain-related symptoms than White individuals after surgeries to correct scoliosis [55] and dental issues [56] and to manage breast cancer [57]. Despite the expressed need for analgesics, Black patients experienced more severe pain and more pain-related interference, but were less likely to be prescribed pain medication despite their pain rating compared to White patients [58-60]. In an attempt to eliminate the provider bias, researchers have sought to examine patient-controlled analgesia (PCA). However, there are limited studies that report powerful results. Unequal treatment of pain between Black and White individuals can result in significant disparities between groups, but it is possible that there are racial differences in the experience of pain that are independent of medication use/availability. Studies with reasonable sample sizes of patients and better study quality are needed to truly understand differences in this area and provide possible mechanisms.

\section{Chronic Non-Cancer Pain}

There are well-documented studies involving racial disparities between Black and White individuals in chronic pain populations [61-64]. White individuals are more likely to report temporomandibular joint (TMJ) and neck pain [65], and facial and jaw pain symptoms than Black individuals, but they appear to have an earlier onset [66]. Although Black individuals report fewer TMJ symptoms, the pain has a greater impact on their daily functioning/tasks [67]. Fibromyalgia appears to affect both Black and White individuals [68]. However, White individuals tend to report significantly increased tenderness in specific areas, while Black individuals report more widespread pain and depressive symptoms [69], once again supporting the notion that the experience of chronic pain conditions differs between races. Black individuals also report more pain and disability than White patients related to chronic low back pain [70] and angina [71]. It has been reported that Black individuals are more likely to express increased pain severity, depression and anxiety, pain-related fear and pain-related disability [72], and a greater sense of suffering and loss of control compared to White individuals $[4,18,61-64,73]$. Black individuals with chronic knee or hip pain also report a lower quality of life [74]. Regardless of the condition, research suggests that the Black population is at greater risk for increased pain severity, pain-related disability, and inadequate pain management $[4,72]$.

\section{Arthritis Pain}

Arthritis is one of the most common manifestations of chronic pain and one of the leading causes of disability in the United State $[75,76]$. According to the National Health Interview Survey, although Black and White individuals had similar rates of arthritis, Black individuals reported much more severe pain in the affected 
joint [77]. Research has also revealed that Black individuals demonstrate more severe pain and disability due to osteoarthritis than their White counterparts [78, 79]. One non-biological factor that has been considered to underlie differences in the rates of arthritis-related pain between races is the differences in the rates of knee and hip replacements. Studies on large populations of patients, as well as data from national surveys, show that Black individuals are less likely to receive a joint replacement despite demonstrating a need for the procedure [80, 81]. In individuals with rheumatoid arthritis, Black individuals are likely to have a higher score than White individuals on the Clinical Disease Activity Index, a common tool used to assess rheumatological disease severity and symptoms [82]. There is no clear link between increased disease activity and subsequent increases in pain. However, those with higher disease activity were more likely to be physically debilitated by rheumatoid arthritis [83].

\section{Cancer Pain}

A large number of those being treated for cancer live with pain [84], often caused by an injury to the nerves during surgery [85-88] and chemotherapeutic agents that are neurotoxic [89-91], as well as radiation-induced nerve damage [92] and radiation-induced inflammation [93-95]. According to the World Health Organization (WHO), 62\% of racial minorities were undertreated for pain in accordance with the WHO standard for cancer-free pain $[96,97]$. The same pattern was evident in studies analyzing quality of care:; cancer patients who were treated in settings that cared mainly for minorities were more likely than White individuals to receive inadequate analgesics $[98,99]$.

\section{Experimental Pain}

It is very possible that differences in sensitivity to noxious stimuli can underlie racial differences in pain. Several studies have demonstrated differences in pain sensitivity between Black and White individuals, as reviewed by
Edwards et al. [18]. Generally, evoked pain ratings are of greater magnitude in Black individuals [100, 101], and this same group shows lower tolerance for experimental pain [102]. When completing heat pain tasks, Black individuals demonstrate significantly lower pain tolerances and thresholds and report pain at lower temperatures than White individuals [19]. Black individuals are also more likely to rate the thermal pain as more unpleasant [103] and report lower tolerance to ischemic pain (pain due to a lack of blood oxygen in the extremities) [104] and lower thresholds and tolerance to cold stimuli compared to White individuals [105]. In two studies examining mechanical pressure pain, Black individuals demonstrated lower pain threshold and tolerance compared to White individuals [101, 104]. Black research participants also report reduced pain tolerance to electrical stimulation pain, and increased temporal summation of noxious stimuli [106]. Taken together, results of experimental pain studies have demonstrated consistent evidence regarding racial differences in pain sensitivity between Black and White individuals.

\section{RACIAL DIFFERENCES IN DIET}

There is evidence that nutritional intake varies substantially between racial groups, and there are a variety of factors that are known to underlie the relationship between race and dietary habits. Geographic residence is one such factor thought to play a significant role in dietary behaviors. In many cities, a higher percentage of Black individuals live in low-income environments compared to their White counterparts [107]. Neighborhood disadvantage is associated with poorer diet quality [108] and is correlated with excess meat intake and limited consumption of fruits, vegetables, and fish [109]. For those individuals living in low-income environments, access to supermarkets may be limited compared to those living in high-income environments. This notion of food deserts-areas where residents have little to no access to healthy and affordable food optionsis also more often reported in Black neighborhoods [110]. In addition, these areas are more 
likely to report lower quality and a limited selection of foodstuffs [111]. As a result, individuals in low-income neighborhoods are likely to increase their consumption of energy-dense, low-cost items in order to ensure adequate food intake $[112,113]$. In addition to the lack of fresh produce, the proportion of fast food restaurants to residents is higher in Black neighborhoods [110]. Research has shown that even wealthy, college-educated Black individuals may feel marginalized and live in neighborhoods with $30 \%$ less income compared to White neighborhoods, creating a barrier even today [114].

The REasons for Geographic and Racial Differences in Stroke (REGARDS) study provides further evidence that an individual's racial group may be an influential factor in determining food choice. Adherence to plant-based dietary habits (i.e., vegetables of many types, fish, soups) were positively associated with socioeconomic status (SES), showing that White individuals were more likely to stick to a plantbased diet. By contrast, stronger adherence to a "Southern dietary pattern" (i.e., fried food, soda, and processed meats) was reported more among Black respondents [39]. We recently reported a cross-sectional study of the REGARDS data in which we demonstrate that higher adherence to poor-quality diets (including the "Southern" dietary pattern) was associated with an increased relative risk of reporting pain, whereas high adherence to the plant-based dietary pattern was associated with reduced risk for pain [115]. Together, these data support the notion that racial differences in dietary patterns may contribute to racial differences in the risk for and expression of chronic pain in an American sample.

Taste perception is another important factor that appears to vary between races. Current data suggest that there are differences in taste responsiveness, which can alter the perceived taste of foods such as vegetables. Genetics plays a major role in the perception of taste and was first studied in terms of taste blindness [116]. Individuals with variations in the genes that code for structures responding more intensely to bitter tastes are more likely to avoid fruits and vegetables [117-119]. Variation in sweet taste is also known to correlate with vegetable preference $[120,121]$. Although there are limited studies of taste differences among racial groups, it has been reported that Black individuals rate taste sensations such as sweet, salty, and bitter at a higher intensity than White individuals [122]. Taken together, it is possible that genetic differences in taste responsiveness alter the intake of certain foods and may explain differences in food/vegetable intake among these racial groups. Recognizing that there is a difference in sensory experience is important, as it may contribute to an individual's ability to comply with a diet and explain why people gravitate toward or away from certain types of foods, which can have both beneficial and detrimental effects on health through inflammatory pathways.

\section{DIET AND OXIDATIVE STRESS}

Oxidative stress is a biological phenomenon that occurs when there is an imbalance between free radical compounds, such as reactive oxygen species (ROS) or reactive nitrogen species (RNS), and antioxidant defense systems in the body [123-125]. This imbalance leads to the destruction of cells and molecules, impacting the whole system [126]. ROS are a normal byproduct of cellular metabolism of molecular oxygen $[127,128]$, have important roles in many signaling pathways, and aid in the response to change in internal and external environmental conditions [127-130]. Sustained stress creates excessive ROS, creating an environment with high levels of free radicals causing damage to cellular components that can ultimately lead to apoptosis [131]. Oxidative stress and free radicals have been implicated in a host of degenerative conditions including Alzheimer's disease [132], Parkinson's disease [133, 134], cardiovascular disease [135, 136], cancer [137, 138], chronic inflammation [139, 140], and diabetes $[131,141]$. Oxidative stress can be triggered by many sources and is heavily influenced by dietary quality.

Diet types such as the standard American diet (SAD) $[29,30]$ that are rich in processed carbohydrates and saturated fats contribute to increased postprandial oxidative stress and a 
chronically elevated state of oxidative stress [142-146]. A poor-quality diet creates an environment of oxidative stress by increasing the presence of free radicals, reducing antioxidant status and resulting in cell damage [147]. Glucose oxidation is thought to be the main source of free radicals via the diet [131]. Glucose can be oxidized to a superoxide anion radical leading to the production of extremely reactive ROS and RNS if it is not degraded by an antioxidant [148-153]. ROS and other free radicals have also been linked to metabolic imbalances in neural tissues leading to impaired neurotropism [154-156], changes in neurotransmission [157-159], Schwann cell injury [160, 161], and axonopathy [162, 163]. Excess carbohydrates are also known to promote lipid peroxidation of low-density lipoprotein (LDL cholesterol) via superoxide-dependent pathways, which also participates in the generation of free radicals [164, 165]. Finally, a high-carbohydrate diet can lead to the production of advanced glycation end products (AGEs) [166] through glycation: a reaction between excess carbohydrates in the body and other nutrients like lipids, proteins, and nucleic acids [167-171]. These compounds exert their deleterious effects by binding to the receptor for AGEs (RAGE) [167, 172] and stimulating various intracellular signaling pathways [173], which leads to apoptosis, inflammation $[174,175]$, and cell differentiation. This activation can also inhibit a number of enzymes by altering their structures and functions [176], promote free radical formation $[177,178]$, and prevent antiproliferative effects of nitric oxide from occurring $[179,180]$.

In addition to increasing the presence of free radicals in the body, excess carbohydrates also impair the innate antioxidant defense system. Under normal conditions, antioxidants are able to neutralize free radicals and prevent them from creating cellular damage and oxidative stress [181-183]. For example, vitamin E prevents the progression of lipid peroxidation; vitamin $\mathrm{C}$ alongside vitamin $\mathrm{E}$ prevents hydroperoxides from forming; transition metals, such as copper and zinc, are involved in the inhibition of lipid peroxidation; and vitamins A and $\mathrm{E}$ are also considered "scavengers" as they seek out and neutralize free radicals
[151, 178, 184-187]. A summary of the most common antioxidants and their sources can be seen in Table 1. A diet with excess carbohydrates can create a surplus of free radicals that overwhelm the innate antioxidant system, increasing oxidative damage. Furthermore, many poor-quality diets that are high in carbohydrates tend to be vitamin-deficient [188], further reducing the ability of the body to control free radicals.

\section{OXIDATIVE STRESS AND PAIN}

There is emerging evidence suggesting that oxidative stress is involved in the development and maintenance of pain. Although oxidative stress can be caused by many factors such as smoking, excess alcohol consumption, air pollution, and UV light, it is also sensitive to foodstuffs and is directly affected by the meal components [143]. There are studies attributing poor-quality diet to increased pain sensitivity [29-31, 38], possibly through increased oxidative stress. Black individuals are at higher risk for elevated oxidative stress levels [189] and, as previously discussed, are more likely to adhere to a diet pattern that includes excess carbohydrate consumption [39]. Additionally, oxidative stress has been linked to many types of painful conditions, which are often reported at higher rates in Black populations [40]. It may be possible that diet variability influences the differences seen in the prevalence and severity of painful conditions amongst Black and White patients. However, the direct link between oxidative stress and pain is not clearly understood. It is important to note that oxidative stress may contribute to pain in different pathological modalities, all of which are important in the pain experience.

\section{Inflammation}

Inflammation is induced by many biochemical and physical factors such as infection, injury, allergens, and radiation, as well as diet-induced oxidative stress [126, 190, 191]. Chronic inflammation predisposes an organism to various chronic illnesses [192], including chronic 
Table 1 A summary of the most common antioxidants, their reported mechanism of action, sources, and citation(s)

\begin{tabular}{|c|c|c|c|}
\hline Antioxidant & $\begin{array}{l}\text { Mechanism } \\
\text { of action }\end{array}$ & Food sources & References \\
\hline Vitamin C & Nonenzymatic & $\begin{array}{l}\text { Broccoli, oranges, Brussels sprouts, tomatoes, and leafy } \\
\text { green vegetables }\end{array}$ & $\begin{array}{l}\text { Block et al. [214], Levine } \\
\text { et al. [215], Padayatty et al. } \\
\text { [216] }\end{array}$ \\
\hline Vitamin A & Nonenzymatic & $\begin{array}{l}\text { Eggs, spinach, carrots, cod liver oil, and leafy green } \\
\text { vegetables }\end{array}$ & $\begin{array}{l}\text { Block et al. [214], Block } \\
\text { [217] }\end{array}$ \\
\hline Vitamin E & Nonenzymatic & $\begin{array}{l}\text { Wheat germ, nuts, seeds, avocado, fish, leafy green } \\
\text { vegetables }\end{array}$ & $\begin{array}{l}\text { Murphy et al. [218], Reboul } \\
\text { et al. [219] }\end{array}$ \\
\hline Glutathione & Nonenzymatic & Endogenous & Meister [220], Sies [221] \\
\hline $\begin{array}{l}\text { Superoxide } \\
\text { dismutase }\end{array}$ & Enzymatic & Endogenous & $\begin{array}{l}\text { Halliwell [222], Clarkson } \\
\text { et al. [223] }\end{array}$ \\
\hline $\begin{array}{l}\text { Glutathione } \\
\text { peroxidase }\end{array}$ & Enzymatic & Endogenous & $\begin{array}{l}\text { Flohe [224], Clarkson et al. } \\
\qquad \text { [223] }\end{array}$ \\
\hline Catalase & Enzymatic & Endogenous & $\begin{array}{l}\text { Betteridge [225], Chelikani } \\
\text { et al. [226] }\end{array}$ \\
\hline $\begin{array}{l}\text { Glutathione } \\
\text { reductase }\end{array}$ & Enzymatic & Endogenous & $\begin{array}{l}\text { Halliwell [222], Clarkson } \\
\text { et al. [223] }\end{array}$ \\
\hline Lipoic acid & Nonenzymatic & Nuts, seeds, Brussels sprouts, organ meats, red meat & $\begin{array}{l}\text { Shay et al. [227], Rochette } \\
\text { et al. [228] }\end{array}$ \\
\hline Carotenoids & Nonenzymatic & $\begin{array}{l}\text { Carrots, plums, apricots, mangoes, cantaloupe, and } \\
\text { sweet potatoes }\end{array}$ & $\begin{array}{l}\text { Clarkson et al. [223], Rao } \\
\text { et al. [229] }\end{array}$ \\
\hline Coenzyme Q10 & Enzymatic & $\begin{array}{l}\text { Endogenous, organ meats, pork, beef, chicken, fish, leafy } \\
\text { green vegetables, strawberries, beans, nuts, and seeds }\end{array}$ & Pravst et al. [230] \\
\hline Bioflavonoids & Nonenzymatic & Oranges, lemons, apples, and legumes & Cook [231] \\
\hline Copper & Nonenzymatic & $\begin{array}{l}\text { Whole grains, green beans, nuts, potatoes, shellfish, and } \\
\text { organ meats }\end{array}$ & Keis [232] \\
\hline Zinc & Nonenzymatic & $\begin{array}{l}\text { Whole grains, milk and milk products, red meat, } \\
\text { chicken, beans, and nuts }\end{array}$ & Solomons [233] \\
\hline Manganese & Nonenzymatic & $\begin{array}{l}\text { Beans, seeds, nuts, whole grains, leafy green vegetables, } \\
\text { and soybeans }\end{array}$ & Black et al. [234] \\
\hline Selenium & Nonenzymatic & $\begin{array}{l}\text { Whole grains, milk and milk products, pork, beef, } \\
\text { turkey, fish, chicken, shellfish, eggs, and mushrooms }\end{array}$ & Rayman [235] \\
\hline Folic acid & Nonenzymatic & $\begin{array}{l}\text { Whole grains, rice, oranges, leafy green vegetables, and } \\
\text { beans }\end{array}$ & $\begin{array}{l}\text { Dietrich et al. [236], Looman } \\
\text { et al. [237] }\end{array}$ \\
\hline $\begin{array}{l}\text { B Vitamins }\left(\mathrm{B}_{1} \text {, }\right. \\
\mathrm{B}_{2}, \mathrm{~B}_{6} \text { and } \\
\left.\mathrm{B}_{12}\right)\end{array}$ & Nonenzymatic & $\begin{array}{l}\text { Pork, chicken, turkey, fish, whole grains, eggs, leafy } \\
\text { green vegetables, and soybeans }\end{array}$ & $\begin{array}{l}\text { Scott [238], Banjari et al. } \\
\text { [239], Mielgo-Ayuso et al. } \\
\text { [240] }\end{array}$ \\
\hline
\end{tabular}


pain. During the peripheral inflammatory response, mast cells and leukocytes are recruited, leading to a subsequent increase in the uptake of oxygen and an increased release and accumulation of ROS. Accumulation of ROS can result in a cellular cycle of events producing pro-inflammatory mediators such as arachidonic acid, cytokines, and chemokines, which recruit more inflammatory cells and molecules that subsequently create more reactive species [189]. In the context of AGEs, interaction with RAGE causes the induction of intracellular ROS production through activation of NF- $\mathrm{KB}$ (nuclear factor kappa-light-chain-enhancer of activated $B$ cells) and leads to the further production of inflammatory mediators [193]. Many signal transduction cascades and transcription factors have been implicated in oxidative stress pathways, including NF- $\kappa \mathrm{B}$, signal transducer and activator of transcription 3 (STAT3), hypoxia-inducible factor- $1 \alpha$ (HIF$1 \alpha)$, activator protein 1 (AP-1), nuclear factor of activated $\mathrm{T}$ cells, NF-E2 related factor-2 (Nrf2), cyclooxygenase-2(COX-2), inducible nitric oxide synthase (iNOS), inflammatory cytokines such as tumor necrosis factor (TNF), interleukin-1 $\beta$ (IL-1 $\beta$ ), IL-6, chemokine IL-8, and CXC chemokine receptor 4 (CXCR4), as well as alterations in the expression of specific microRNAs [126]. These compounds can directly stimulate nociceptors and other afferent neurons, resulting in pain. It has been reported that Black individuals have exaggerated levels of basal oxidative stress and inflammation [189] even in the absence of injury [194]. Taken together, this suggests that dietary makeup may have a greater negative impact on oxidative stress and subsequent pain in this group.

\section{Neuropathy and Neuropathic Pain}

Neuropathy-often referred to as peripheral neuropathy-refers to a group of conditions characterized by abnormal function of the nerves in the peripheral nervous system due to damage or disease. Symptoms can range from numbness/tingling to intense neuropathic pain and loss of function [195]. While there are other noted risk factors for neuropathy, such as repetitive movements and injuries or chemotherapy, diet-induced oxidative stress can also exert deleterious effects on the structure and function of nerve cells. In fact, it has been shown that poor glycemic control is an independent risk factor for the development of diabetic neuropathy [196]. At a cellular level, neuronal apoptosis has been shown to occur from exposure to both ROS and RNS [197]. Lipids that are present in various organelles such as the mitochondria, endoplasmic reticulum, and cytoplasm are major targets of ROS damage, and the resulting lipid peroxides can be neurotoxic upon accumulation. Axonal transport of important neurotransmitters, growth factors, and other intermediates can also be slowed in such an environment, which can result in induced apoptosis of the neuron [198]. Resulting increases in AGEs can induce a feedforward cascade of progressive neuronal dysfunction and impaired neurotropic support in the short term, and can cause apoptosis of the whole neuron or injury to supporting cells, such as Schwann cells, that are important in the conduction of nerve signals [199]. Upon neuronal injury, macrophages respond by infiltrating the injured site. Here, they express many surface cell markers and secrete cytokines and chemokines. Macrophages in the periphery work similarly to microglia in the central nervous system [200] to remove cellular debris and dead neurons through Wallerian degeneration, allowing for regrowth of the injured axon (in the periphery) [201]. This process of degeneration and regeneration of the injured cell is hypothesized to be a part of the pathogenesis of neuropathic pain and sclerosis, in addition to the actual dysfunction and neuronal death as a result of oxidative stress [202]. AGEs can act as a "danger signal," much like pathogens or intermediates produced from neuronal apoptosis, activating macrophages without any actual damage [203]. Following priming of peripheral immune cells, it has been observed that, upon stimulation by other danger signals, these macrophages display an exacerbated response, which may contribute to the development of neuropathic pain [204]. According to a 2017 study exploring the prevalence of neuropathic pain in the United States, there was significant 
racial variation amongst those who reported these symptoms, with Black individuals representing a much larger percentage of the sample than White individuals, despite being a smaller proportion of the overall population [205]. It is possible that the variation in glycemic load as a result of differing dietary carbohydrate intake could play a significant role in this difference. While neuropathies are known to have heterogeneous etiologies, the acknowledgement of diet-induced oxidative stress is a critical factor to advance our understanding of these conditions.

It is widely accepted that poor-quality diets can be detrimental to one's health, including potential exacerbation of the pain experience via oxidative stress and inflammation. Therefore, it would be efficacious to explore the effects that higher-quality diets have on the prevention and possible reversal of chronic pain. Dietary interventions for chronic pain have gained traction as a possible alternative treatment modality, and investigations of dietary intake have shown that many individuals with chronic pain have an imbalance in the free radical to antioxidant ratio and that reversing this imbalance can alleviate pain [206] There is clinical evidence that vitamin $\mathrm{C}$, a common antioxidant found in many fruits and vegetables, may have a protective effect against the development of complex regional pain syndrome (CRPS) through its ability to reduce oxidative stress [207]. Treatment with vitexin (a common flavonoid in plants) for inflammatory injury via phenyl-p-benzoquinone, complete Freund's adjuvant, formalin, or capsaicin inhibited pain-like behavior in mice. This treatment also lowered oxidative stress and proinflammatory mediators, and increased antioxidant capacity and anti-inflammatory compounds [208], demonstrating a potential link between oxidative stress and pain. Supplementation with vitamin B12 has been shown to reduce markers of oxidative stress and inflammation [209], and can lead to reductions in pain scores and use of analgesics in patients with low back pain [210]. Furthermore, it has been suggested that consuming $1000 \mu \mathrm{g} /$ day may improve symptoms of pain [211]. Curcumin, the active ingredient in the spice turmeric and black pepper, has also been shown to act as an antioxidant, reduce oxidative stress, and improve pain caused by diabetic neuropathy [212]. These exploratory studies have expanded the body of evidence supporting the use of food for treatment of painful conditions. However, more work needs to be done to understand the efficacy of these foods and supplements across racial groups.

\section{CONCLUSION}

Racial differences in chronic pain prevalence and burden of the pain exist, in that Black individuals are disproportionately affected [20-24]. This racial group has higher rates of most chronic pain conditions, but also report more severe and intense pain compared to their White counterparts [106]. There are many possibilities as to why these differences are observed-genetics, psychosocial variables, and unequal care [4, 25-28]. In addition, differences in diet patterns between the two racial groups [39] is an important factor that has been overlooked in this area of research. Of particular importance is the variability between the amount of carbohydrates and unhealthy fats consumed within each racial group [213]. Black individuals consume significantly more of these macronutrients, even when controlling for other factors influencing diet [39, 108, 110]. Carbohydrates can increase oxidative stress [143-146], perhaps resulting in the observed elevated levels of systemic inflammation [126] and oxidative stress [189] in Black populations when compared to White populations. Therefore, variability in food intake between racial groups may underlie racial differences in chronic pain. We have shown that a diet intervention can reduce pain and oxidative stress [38], but it is possible that a reduced carbohydrate diet has greater benefit based on racial group. Thus, it is encouraged that future studies aim to further understand the relationship between diet, oxidative stress/inflammation, and pain outcomes across races. Dietary interventions and nutritional education are safer, more modifiable treatments with less risk of negative side effects and other complications, 
which may limit the reliance on opioid analgesics. Most critically, dietary interventions may provide a means to reduce racial differences in chronic pain.

\section{ACKNOWLEDGEMENTS}

The authors would like to acknowledge Tammie Quinn, Demario Overstreet, Suzanne Judd, Burel Goodin, Jose Fernandez, and Jarred Younger for their aid in the conceptualization and support of the manuscript.

Funding. No funding or sponsorship was received for this study or publication of this article.

Authorship. All named authors meet the International Committee of Medical Journal Editors (ICMJE) criteria for authorship for this article, take responsibility for the integrity of the work as a whole, and have given their approval for this version to be published.

Author Contributions. LJS performed the literature review and wrote the manuscript. RES edited the manuscript and gave feedback on the overall design and format.

Disclosures. The authors (Larissa Strath and Robert Sorge) have nothing to disclose.

Compliance and Ethics Guidelines. This article is based on previously conducted studies and does not contain any new studies with human participants or animals performed by any of the authors.

Open Access. This article is licensed under a Creative Commons Attribution-NonCommercial 4.0 International License, which permits any non-commercial use, sharing, adaptation, distribution and reproduction in any medium or format, as long as you give appropriate credit to the original author(s) and the source, provide a link to the Creative Commons licence, and indicate if changes were made. The images or other third party material in this article are included in the article's Creative Commons licence, unless indicated otherwise in a credit line to the material. If material is not included in the article's Creative Commons licence and your intended use is not permitted by statutory regulation or exceeds the permitted use, you will need to obtain permission directly from the copyright holder. To view a copy of this licence, visit http://creativecommons.org/licenses/by$\mathrm{nc} / 4.0 /$.

\section{REFERENCES}

1. Thorpe KE. Factors accounting for the rise in healthcare spending in the United States: the role of rising disease prevalence and treatment intensity. Public Health. 2006;120(11):1002-7. https://doi.org/10. 1016/j.puhe.2006.09.001.

2. Nahin RL. Estimates of pain prevalence and severity in adults: United States, 2012. J Pain. 2015;16(8): 769-80. https://doi.org/10.1016/j.jpain.2015.05. 002.

3. Verhaak PF, Kerssens JJ, Dekker J, Sorbi MJ, Bensing JM. Prevalence of chronic benign pain disorder among adults: a review of the literature. Pain. 1998;77(3):231-9.

4. Green CR, Anderson KO, Baker TA, et al. The unequal burden of pain: confronting racial and ethnic disparities in pain. Pain Med. 2003;4(3): 277-94.

5. Green CR. Being present: the role of narrative medicine in reducing the unequal burden of pain. Pain. 2011;152(5):965-6. https://doi.org/10.1016/j. pain.2011.01.041.

6. Johannes CB, Le TK, Zhou X, Johnston JA, Dworkin $\mathrm{RH}$. The prevalence of chronic pain in United States adults: results of an Internet-based survey. J Pain. 2010;11(11):1230-9. https://doi.org/10.1016/j. jpain.2010.07.002.

7. Mao J. Challenges of managing chronic pain. BMJ. 2017;356:j741. https://doi.org/10.1136/bmj.j741.

8. Vowles KE, McEntee ML, Julnes PS, Frohe T, Ney JP, van der Goes DN. Rates of opioid misuse, abuse, and addiction in chronic pain: a systematic review and data synthesis. Pain. 2015;156(4):569-76. https:// doi.org/10.1097/01.j.pain.0000460357.01998.f1.

9. Control CfD. Vital signs: overdoses of prescription opioid pain relievers--United States, 1999-2008. Morbidity and Mortality Weekly Report (MMWR). 
10. Bolash RB. Trends in opioid analgesic abuse and mortality in the United States. N Engl J Med. 2015;372(16):1573. https://doi.org/10.1056/ NEJMc1501822.

11. McCann DJ, Skolnick P. Trends in opioid analgesic abuse and mortality in the United States. N Engl J Med. 2015;372(16):1572-3. https://doi.org/10. 1056/NEJMc1501822.

12. Rosen SF, Ham B, Haichin M, et al. Increased pain sensitivity and decreased opioid analgesia in T celldeficient mice and implications for sex differences. Pain. 2018. https://doi.org/10.1097/j.pain. 0000000000001420.

13. Mogil JS, Bailey AL. Sex and gender differences in pain and analgesia. Rev Progress Brain Res. 2010;186:141-57. https://doi.org/10.1016/B978-0444-53630-3.00009-9.

14. Mogil JS, Chesler EJ, Wilson SG, Juraska JM, Sternberg WF. Sex differences in thermal nociception and morphine antinociception in rodents depend on genotype. Neurosci Biobehav Rev. 2000;24(3): 375-89.

15. Mogil JS. Sex differences in pain and pain inhibition: multiple explanations of a controversial phenomenon. Research Support, N.I.H., Extramural Research Support, Non-U.S. Gov't. Nat Rev Neurosci. 2012;13(12):859-66. https://doi.org/10.1038/ nrn3360.

16. Elliott AM, Smith BH, Penny KI, Smith WC, Chambers WA. The epidemiology of chronic pain in the community. Lancet. 1999;354(9186): $1248-52$.

17. Sorge RESLJ. Sex differences in pain responses. Curr Opin Physiol. 2018;6:75-81.

18. Edwards CL, Fillingim RB, Keefe F. Race, ethnicity and pain. Pain. 2001;94(2):133-7.

19. Chapman WP, Jones CM. Variations in cutaneous and visceral pain sensitivity in normal subjects. J Clin Investig. 1944;23(1):81-91. https://doi.org/ 10.1172/JCI101475.

20. Bonham VL. Race, ethnicity, and pain treatment: striving to understand the causes and solutions to the disparities in pain treatment. J Law Med Ethics. 2001;29(1):52-68.

21. Orhan C, Van Looveren E, Cagnie B, Mukhtar NB, Lenoir D, Meeus M. Are pain beliefs, cognitions, and behaviors influenced by race, ethnicity, and culture in patients with chronic musculoskeletal pain: a systematic review. Pain Phys. 2018;21(6):541-58.
22. Meints SM, Wang V, Edwards RR. Sex and race differences in pain sensitization among patients with chronic low back pain. J Pain. 2018;19(12):1461-70. https://doi.org/10.1016/j.jpain.2018.07.001.

23. Milani CJ, Rundell SD, Jarvik JG, et al. Associations of race and ethnicity with patient-reported outcomes and health care utilization among older adults initiating a new episode of care for back pain. Spine (Phila Pa 1976). 2018;43(14):1007-17. https:// doi.org/10.1097/BRS.0000000000002499.

24. Fuentes M, Hart-Johnson T, Green CR. The association among neighborhood socioeconomic status, race and chronic pain in black and white older adults. J Natl Med Assoc. 2007;99(10):1160-9.

25. Ossorio P, Duster T. Race and genetics: controversies in biomedical, behavioral, and forensic sciences. Am Psychol. 2005;60(1):115-28. https://doi. org/10.1037/0003-066X.60.1.115.

26. Williams DR, Jackson PB. Social sources of racial disparities in health. Health Aff. 2005;24(2):325-34. https://doi.org/10.1377/hlthaff.24.2.325.

27. Cano A, Mayo A, Ventimiglia M. Coping, pain severity, interference, and disability: the potential mediating and moderating roles of race and education. J Pain. 2006;7(7):459-68. https://doi.org/10. 1016/j.jpain.2006.01.445.

28. Hiza HA, Casavale KO, Guenther PM, Davis CA. Diet quality of Americans differs by age, sex, race/ ethnicity, income, and education level. J Acad Nutr Diet. 2013;113(2):297-306. https://doi.org/10. 1016/j.jand.2012.08.011.

29. Totsch SK, Meir RY, Quinn TL, Lopez SA, Gower BA, Sorge RE. Effects of a standard American Diet and an Anti-inflammatory Diet in Male and Female Mice. Eur J Pain. 2018. https://doi.org/10.1002/ejp.1207.

30. Totsch SK, Quinn TL, Strath LJ, et al. The impact of the Standard American Diet in rats: Effects on behavior, physiology and recovery from inflammatory injury. Scand J Pain. 2017;17:316-24. https:// doi.org/10.1016/j.sjpain.2017.08.009.

31. Totsch SK, Sorge RE. Immune system involvement in specific pain conditions. Mol Pain. 2017;13: 1744806917724559. https://doi.org/10.1177/ 1744806917724559 .

32. Allison DJ, Ditor DS. Maintenance of diet participation in individuals with spinal cord injury: effect on mood and neuropathic pain. Spinal Cord Ser Cases. 2018;4:97. https://doi.org/10.1038/s41394018-0131-2.

33. Towery P, Guffey JS, Doerflein C, Stroup K, Saucedo S, Taylor J. Chronic musculoskeletal pain and 
function improve with a plant-based diet. Complement Ther Med. 2018;40:64-9. https://doi.org/10. 1016/j.ctim.2018.08.001.

34. Guillemot-Legris O, Buisseret B, Mutemberezi V, et al. Post-operative pain in mice is prolonged by diet-induced obesity and rescued by dietary intervention. Brain Behav Immun. 2018;74:96-105. https://doi.org/10.1016/j.bbi.2018.07.022.

35. Marziali M, Capozzolo T. Role of gluten-free diet in the management of chronic pelvic pain of deep infiltranting endometriosis. J Minim Invasive Gynecol. 2015;22(6S):S51-2. https://doi.org/10. 1016/j.jmig.2015.08.142.

36. Boradyn KM, Przybylowicz KE. Low FODMAP diet: a potential treatment of functional abdominal pain in children. Perspect Public Health. 2017;137(6): 314-5. https://doi.org/10.1177/1757913917730253.

37. Totsch SK, Quinn TL, Strath LJ, et al. The impact of the Standard American Diet in rats: Effects on behavior, physiology and recovery from inflammatory injury. Scand J Pain. 2017. https://doi.org/10. 1016/j.sjpain.2017.08.009.

38. Strath LJ, Jones CD, Philip George A, et al. The effect of low-carbohydrate and low-fat diets on pain in individuals with knee osteoarthritis. Pain Med. 2020;21(1):150-60. https://doi.org/10.1093/pm/ pnz022.

39. Kell KP, Judd SE, Pearson KE, Shikany JM, Fernandez JR. Associations between socio-economic status and dietary patterns in US black and white adults. Br J Nutr. 2015;113(11):1792-9. https://doi.org/10. 1017/S0007114515000938.

40. Morris AA, Zhao L, Patel RS, et al. Differences in systemic oxidative stress based on race and the metabolic syndrome: the Morehouse and Emory Team up to Eliminate Health Disparities (METAHealth) study. Metab Syndr Relat Disord. 2012;10(4):252-9. https://doi.org/10.1089/met. 2011.0117.

41. Todd KH. Pain assessment and ethnicity. Ann Emerg Med. 1996;27(4):421-3.

42. Todd KH, Lee T, Hoffman JR. The effect of ethnicity on physician estimates of pain severity in patients with isolated extremity trauma. JAMA. 1994;271(12):925-8.

43. Reyes-Gibby CC, Aday LA, Todd KH, Cleeland CS, Anderson KO. Pain in aging community-dwelling adults in the United States: non-Hispanic whites, non-Hispanic blacks, and Hispanics. J Pain. 2007;8(1):75-84. https://doi.org/10.1016/j.jpain. 2006.06.002.
44. Aufiero M, Stankewicz H, Quazi S, Jacoby J, Stoltzfus J. Pain perception in Latino vs. Caucasian and Male vs. female patients: is there really a difference? West J Emerg Med. 2017;18(4):737-42. https://doi.org/ 10.5811/westjem.2017.1.32723.

45. Todd KH, Deaton C, D'Adamo AP, Goe L. Ethnicity and analgesic practice. Ann Emerg Med. 2000;35(1): $11-6$.

46. Todd KH, Samaroo N, Hoffman JR. Ethnicity as a risk factor for inadequate emergency department analgesia. JAMA. 1993;269(12):1537-9.

47. Heins JK, Heins A, Grammas M, Costello M, Huang $\mathrm{K}$, Mishra S. Disparities in analgesia and opioid prescribing practices for patients with musculoskeletal pain in the emergency department. J Emerg Nurs. 2006;32(3):219-24. https://doi.org/ 10.1016/j.jen.2006.01.010.

48. Hostetler MA, Auinger P, Szilagyi PG. Parenteral analgesic and sedative use among ED patients in the United States: combined results from the National Hospital Ambulatory Medical Care Survey (NHAMCS) 1992-1997. Am J Emerg Med. 2002;20(3):139-43.

49. Tamayo-Sarver JH, Hinze SW, Cydulka RK, Baker DW. Racial and ethnic disparities in emergency department analgesic prescription. Am J Public Health. 2003;93(12):2067-73.

50. Fuentes EF, Kohn MA, Neighbor ML. Lack of association between patient ethnicity or race and fracture analgesia. Acad Emerg Med. 2002;9(9):910-5.

51. Gerson LW, Emond JA, Camargo CA Jr. US emergency department visits for hip fracture, 1992-2000. Eur J Emerg Med. 2004;11(6):323-8.

52. Quazi S, Eberhart M, Jacoby J, Heller M. Are racial disparities in ED analgesia improving? Evidence from a national database. Am J Emerg Med. 2008;26(4):462-4. https://doi.org/10.1016/j.ajem. 2007.05.007

53. Singer AJ, Thode HC Jr. National analgesia prescribing patterns in emergency department patients with burns. J Burn Care Rehabil. 2002;23(6):361-5. https://doi.org/10.1097/01.BCR.0000036622. 74117.E0.

54. Yen K, Kim M, Stremski ES, Gorelick MH. Effect of ethnicity and race on the use of pain medications in children with long bone fractures in the emergency department. Ann Emerg Med. 2003;42(1):41-7. https://doi.org/10.1067/mem.2003.230.

55. White SF, Asher MA, Lai SM, Burton DC. Patients' perceptions of overall function, pain, and appearance after primary posterior instrumentation and 
fusion for idiopathic scoliosis. Spine (Phila Pa 1976). 1999;24(16):1693.

56. Faucett J, Gordon N, Levine J. Differences in postoperative pain severity among four ethnic groups. J Pain Symptom Manag. 1994;9(6):383-9.

57. Eversley R, Estrin D, Dibble S, Wardlaw L, Pedrosa M, Favila-Penney W. Post-treatment symptoms among ethnic minority breast cancer survivors. Oncol Nurs Forum. 2005;32(2):250-6. https://doi. org/10.1188/05.ONF.250-256.

58. McNeill JA, Sherwood GD, Starck PL. The hidden error of mismanaged pain: a systems approach. J Pain Symptom Manag. 2004;28(1):47-58. https:// doi.org/10.1016/j.jpainsymman.2003.11.005.

59. Ng B, Dimsdale JE, Rollnik JD, Shapiro H. The effect of ethnicity on prescriptions for patient-controlled analgesia for post-operative pain. Pain. 1996;66(1): 9-12.

60. Ng B, Dimsdale JE, Shragg GP, Deutsch R. Ethnic differences in analgesic consumption for postoperative pain. Psychosom Med. 1996;58(2):125-9.

61. Riley JL 3rd, Wade JB, Myers CD, Sheffield D, Papas RK, Price DD. Racial/ethnic differences in the experience of chronic pain. Pain. 2002;100(3): 291-8.

62. Green CR, Baker TA, Sato Y, Washington TL, Smith EM. Race and chronic pain: A comparative study of young black and white Americans presenting for management. J Pain. 2003;4(4):176-83.

63. McCracken LM, Matthews AK, Tang TS, Cuba SL. A comparison of blacks and whites seeking treatment for chronic pain. Clin J Pain. 2001;17(3):249-55.

64. Edwards RR, Doleys DM, Fillingim RB, Lowery D. Ethnic differences in pain tolerance: clinical implications in a chronic pain population. Psychosom Med. 2001;63(2):316-23. https://doi.org/10.1097/ 00006842-200103000-00018.

65. Plesh O, Adams SH, Gansky SA. Racial/Ethnic and gender prevalences in reported common pains in a national sample. J Orofac Pain. 2011;25(1):25-31.

66. Plesh O, Crawford PB, Gansky SA. Chronic pain in a biracial population of young women. Pain. 2002;99(3):515-23.

67. Riley JL 3rd, Gilbert GH, Heft MW. Orofacial pain: racial and sex differences among older adults. J Public Health Dent. 2002;62(3):132-9.

68. Walitt B, Nahin RL, Katz RS, Bergman MJ, Wolfe F. The Prevalence and characteristics of fibromyalgia in the 2012 National Health Interview Survey. PLoS
ONE. 2015;10(9): e0138024. https://doi.org/10. 1371/journal.pone.0138024.

69. Gansky SA, Plesh O. Widespread pain and fibromyalgia in a biracial cohort of young women. J Rheumatol. 2007;34(4):810-7.

70. Carey TS, Garrett JM. The relation of race to outcomes and the use of health care services for acute low back pain. Spine. 2003;28(4):390-4. https://doi. org/10.1097/01.BRS.0000048499.25275.51.

71. Hendrix KH, Mayhan S, Lackland DT, Egan BM. Prevalence, treatment, and control of chest pain syndromes and associated risk factors in hypertensive patients. Am J Hypertens. 2005;18(8):1026-32. https://doi.org/10.1016/j.amjhyper.2005.02.016.

72. Anderson KO, Green CR, Payne R. Racial and ethnic disparities in pain: causes and consequences of unequal care. J Pain. 2009;10(12):1187-204. https:// doi.org/10.1016/j.jpain.2009.10.002.

73. Green CR, Baker TA, Smith EM, Sato Y. The effect of race in older adults presenting for chronic pain management: a comparative study of black and white Americans. J Pain. 2003;4(2):82-90.

74. Ibrahim SA, Siminoff LA, Burant CJ, Kwoh CK. Differences in expectations of outcome mediate African American/white patient differences in "willingness" to consider joint replacement. Arthritis Rheum. 2002;46(9):2429-35. https://doi. org/10.1002/art.10494.

75. Baker TA, Whitfield KE. Physical functioning in older blacks: an exploratory study identifying psychosocial and clinical predictors. J Natl Med Assoc. 2006;98(7):1114-20.

76. Baker TA. Arthritis symptoms as indicators of pain in older African Americans. Ethn Dis Fall. 2003;13(4):513-20.

77. CDC. Racial/ethnic differences in the prevalence and impact of doctor-diagnosed arthritis. 2002;54: 119-123 (2019).

78. Dominick KL, Bosworth HB, Jeffreys AS, Grambow SC, Oddone EZ, Horner RD. Racial/ethnic variations in non-steroidal anti-inflammatory drug (NSAID) use among patients with osteoarthritis. Pharmacoepidemiol Drug Saf. 2004;13(10):683-94. https:// doi.org/10.1002/pds.904.

79. Golightly YM, Dominick KL. Racial variations in self-reported osteoarthritis symptom severity among veterans. Aging Clin Exp Res. 2005;17(4): 264-9.

80. Steel N, Clark A, Lang IA, Wallace RB, Melzer D. Racial disparities in receipt of hip and knee joint 
replacements are not explained by need: the Health and Retirement Study 1998-2004. J Gerontol A Biol Sci Med Sci. 2008;63(6):629-34.

81. Skinner J, Zhou W, Weinstein J. The influence of income and race on total knee arthroplasty in the United States. J Bone Jt Surg Am. 2006;88(10): 2159-66. https://doi.org/10.2106/JBJS.E.00271.

82. Greenberg JD, Spruill TM, Shan Y, et al. Racial and ethnic disparities in disease activity in patients with rheumatoid arthritis. Am J Med. 2013;126(12): 1089-98. https://doi.org/10.1016/j.amjmed.2013. 09.002 .

83. Rheumatology H. Disease activity may be masked by lower pain in older patients with RA. Healio; 2019.

84. Polomano RC, Farrar JT. Pain and neuropathy in cancer survivors. Surgery, radiation, and chemotherapy can cause pain; research could improve its detection and treatment. Am J Nurs. 2006;106(3 Suppl):39-47.

85. Marchettini P, Formaglio F, Lacerenza M. Iatrogenic painful neuropathic complications of surgery in cancer. Acta Anaesthesiol Scand. 2001;45(9): 1090-4.

86. Chua KS, Reddy SK, Lee MC, Patt RB. Pain and loss of function in head and neck cancer survivors. J Pain Symptom Manag. 1999;18(3):193-202.

87. Karmakar MK, Ho AM. Postthoracotomy pain syndrome. Thorac Surg Clin. 2004;14(3):345-52. https://doi.org/10.1016/S1547-4127(04)00022-2.

88. Macdonald L, Bruce J, Scott NW, Smith WC, Chambers WA. Long-term follow-up of breast cancer survivors with post-mastectomy pain syndrome. Br J Cancer. 2005;92(2):225-30. https://doi.org/10. 1038/sj.bjc. 6602304.

89. Visovsky C. Chemotherapy-induced peripheral neuropathy. Cancer Invest. 2003;21(3):439-51.

90. Polomano RC, Bennett GJ. Chemotherapy-evoked painful peripheral neuropathy. Pain Med. 2001;2(1):8-14. https://doi.org/10.1046/j.15264637.2001.002001008.x.

91. Xiao W, Boroujerdi A, Bennett GJ, Luo ZD. Chemotherapy-evoked painful peripheral neuropathy: analgesic effects of gabapentin and effects on expression of the alpha-2-delta type-1 calcium channel subunit. Neuroscience. 2007;144(2): 714-20. https://doi.org/10.1016/j.neuroscience. 2006.09.044.

92. Azinovic I, Calvo FA, Puebla F, Aristu J, MartinezMonge R. Long-term normal tissue effects of intraoperative electron radiation therapy (IOERT): late sequelae, tumor recurrence, and second malignancies. Int J Radiat Oncol Biol Phys. 2001;49(2): 597-604.

93. Lyne ME, Coyne PJ, Watson AC. Pain management issues for cancer survivors. Cancer Pract. 2002;10(Suppl 1):S27-32.

94. Portenoy RK. Cancer pain: pathophysiology and syndromes. Lancet. 1992;339(8800):1026-31.

95. Portenoy RK, Ahmed E. Cancer pain syndromes. Hematol Oncol Clin N Am. 2018;32(3):371-86. https://doi.org/10.1016/j.hoc.2018.01.002.

96. Cleeland CS, Gonin R, Hatfield AK, et al. Pain and its treatment in outpatients with metastatic cancer. N Engl J Med. 1994;330(9):592-6. https://doi.org/ 10.1056/NEJM199403033300902.

97. Cleeland CS, Gonin R, Baez L, Loehrer P, Pandya KJ. Pain and treatment of pain in minority patients with cancer. The Eastern Cooperative Oncology Group Minority Outpatient Pain Study. Ann Intern Med. 1997;127(9):813-6.

98. Anderson KO, Mendoza TR, Valero V, et al. Minority cancer patients and their providers: pain management attitudes and practice. Cancer. 2000;88(8): 1929-38.

99. Anderson KO, Richman SP, Hurley J, et al. Cancer pain management among underserved minority outpatients: perceived needs and barriers to optimal control. Cancer. 2002;94(8):2295-304. https://doi. org/10.1002/cncr.10414.

100. Riley JL 3rd, Cruz-Almeida Y, Glover TL, et al. Age and race effects on pain sensitivity and modulation among middle-aged and older adults. J Pain. 2014;15(3):272-82. https://doi.org/10.1016/j.jpain. 2013.10.015

101. Woodrow KM, Friedman GD, Siegelaub AB, Collen MF. Pain tolerance: differences according to age, sex and race. Psychosom Med. 1972;34(6):548-56.

102. Meints SM, Stout M, Abplanalp S, Hirsh AT. Painrelated rumination, but not magnification or helplessness, mediates race and sex differences in experimental pain. J Pain. 2017;18(3):332-9. https://doi.org/10.1016/j.jpain.2016.11.005.

103. Edwards RR, Fillingim RB. Ethnic differences in thermal pain responses. Psychosom Med. 1999;61(3):346-54.

104. Rahim-Williams FB, Riley JL 3rd, Herrera D, Campbell CM, Hastie BA, Fillingim RB. Ethnic identity predicts experimental pain sensitivity in African Americans and Hispanics. Pain. 2007;129(1-2): 
177-84. https://doi.org/10.1016/j.pain.2006.12. 016.

105. Rahim-Williams B, Riley JL 3rd, Williams AK, Fillingim RB. A quantitative review of ethnic group differences in experimental pain response: do biology, psychology, and culture matter? Pain Med. 2012;13(4):522-40. https://doi.org/10.1111/j.15264637.2012.01336.x.

106. Campbell CM, Edwards RR. Ethnic differences in pain and pain management. Pain Manag. 2012;2(3): 219-30. https://doi.org/10.2217/pmt.12.7.

107. Simms MC, Fortuny K, Henderson E. Racial and ethic disparities among low-income families. LIWF Fact Sheet. The Urban Institute; 2009.

108. Keita AD, Casazza K, Thomas O, Fernandez JR. Neighborhood perceptions affect dietary behaviors and diet quality. J Nutr Educ Behav. 2011;43(4): 244-50. https://doi.org/10.1016/j.jneb.2009.07. 004.

109. Diez-Roux AV, Neito FJ, Caulfield L, Tyroler HA, Watson RL, Szklo M. Neighborhood differences in diet: the Atherosclerosis Risk in Communities (ARIC) Study. J Epidemiol Community Health. 1999;53:55-63.

110. Kwate NO. Fried chicken and fresh apples: racial segregation as a fundamental cause of fast food density in black neighborhoods. Health Place. 2008;14(1):32-44. https://doi.org/10.1016/j. healthplace.2007.04.001.

111. Hall BD. Teschler-Nicola/Killian syndrome: a sporadic case in an 11-year-old male. J Clin Dysmorphol Fall. 1983;1(3):14-7.

112. Fuentes Pacheco A, Carrillo Balam G, Archibald D, Grant E, Skafida V. Exploring the relationship between local food environments and obesity in UK, Ireland, Australia and New Zealand: a systematic review protocol. BMJ Open. 2018;8(2):e018701. https://doi.org/10.1136/bmjopen-2017-018701.

113. Alaimo K, Olson CM, Frongillo EA Jr. Low family income and food insufficiency in relation to overweight in US children: is there a paradox? Arch Pediatr Adolesc Med. 2001;155(10):1161-7.

114. Vicenzi EP, Eggins S, Logan A, Wysoczanski R. Microbeam characterization of corning archeological reference glasses: new additions to the smithsonian microbeam standard collection. J Res Natl Inst Stand Technol. 2002;107(6):719-27. https:// doi.org/10.6028/jres.107.058.

115. Strath LJ, Brooks MS, Sorge RE, Judd SE. Relationship between diet and relative risk of pain in a crosssectional analysis of the REGARDS longitudinal study. Pain Manag. 2021. https://doi.org/10.2217/ pmt-2021-0048.

116. Fox AL. The relationship between chemical constitution and taste. Proc Natl Acad Sci U S A. 1932;18(1):115-20.

117. Fischer ME, Cruickshanks KJ, Schubert CR, et al. The association of taste with change in adiposity-related health measures. J Acad Nutr Diet. 2014;114(8): 1195-202. https://doi.org/10.1016/j.jand.2014.04. 013.

118. Glanville EV, Kaplan AR. Food preference and sensitivity of taste for bitter compounds. Nature. 1965;205:851-3.

119. Jerzsa-Latta M, Krondl M, Coleman P. Use and perceived attributes of cruciferous vegetables in terms of genetically-mediated taste sensitivity. Appetite. 1990;15(2):127-34.

120. Drewnowski A, Henderson SA, Levine A, Hann C. Taste and food preferences as predictors of dietary practices in young women. Public Health Nutr. 1999;2(4):513-9.

121. Dinehart ME, Hayes JE, Bartoshuk LM, Lanier SL, Duffy VB. Bitter taste markers explain variability in vegetable sweetness, bitterness, and intake. Physiol Behav. 2006;87(2):304-13. https://doi.org/10.1016/ j.physbeh.2005.10.018.

122. Williams JA, Bartoshuk LM, Fillingim RB, Dotson CD. Exploring ethnic differences in taste perception. Chem Senses. 2016;41(5):449-56. https://doi. org/10.1093/chemse/bjw021.

123. Guo TZ, Wei T, Huang TT, Kingery WS, Clark JD. Oxidative stress contributes to fracture/cast-induced inflammation and pain in a rat model of complex regional pain syndrome. J Pain. 2018;19(10):1147-56. https://doi.org/10.1016/j. jpain.2018.04.006.

124. Hussain SP, Hofseth LJ, Harris CC. Radical causes of cancer. Nat Rev Cancer. 2003;3(4):276-85. https:// doi.org/10.1038/nrc1046.

125. Zou D, Li J, Fan Q, Zheng X, Deng J, Wang S. Reactive oxygen and nitrogen species induce cell apoptosis via a mitochondria-dependent pathway in hyperoxia lung injury. J Cell Biochem. 2018. https://doi.org/10.1002/jcb.27382.

126. Reuter S, Gupta SC, Chaturvedi MM, Aggarwal BB. Oxidative stress, inflammation, and cancer: how are they linked? Free Radic Biol Med. 2010;49(11): 1603-16. https://doi.org/10.1016/j.freeradbiomed. 2010.09.006. 
127. Fridovich I. The biology of oxygen radicals. Science. 1978;201(4359):875-80.

128. Manso C. Oxygen radicals in biology. Acta Med Port. 1984;5(3):103-7 (Radicais de oxigenio em biologia).

129. Jabs T. Reactive oxygen intermediates as mediators of programmed cell death in plants and animals. Biochem Pharmacol. 1999;57(3):231-45.

130. Goossens V, De Vos K, Vercammen D, et al. Redox regulation of TNF signaling. Biofactors. $1999 ; 10(2-3): 145-56$.

131. Maritim AC, Sanders RA, Watkins JB 3rd. Diabetes, oxidative stress, and antioxidants: a review. J Biochem Mol Toxicol. 2003;17(1):24-38. https:// doi.org/10.1002/jbt.10058.

132. Balazs L, Leon M. Evidence of an oxidative challenge in the Alzheimer's brain. Neurochem Res. 1994;19(9):1131-7.

133. Jenner P. Oxidative damage in neurodegenerative disease. Lancet. 1994;344(8925):796-8.

134. Spencer JP, Jenner A, Aruoma OI, et al. Intense oxidative DNA damage promoted by L-dopa and its metabolites. Implications for neurodegenerative disease. FEBS Lett. 1994;353(3):246-50.

135. Kayama Y, Raaz U, Jagger A, et al. diabetic cardiovascular disease induced by oxidative stress. Int J Mol Sci. 2015;16(10):25234-63. https://doi.org/10. 3390/ijms161025234.

136. Csanyi G, Miller FJ Jr. Oxidative stress in cardiovascular disease. Int J Mol Sci. 2014;15(4):6002-8. https://doi.org/10.3390/ijms15046002.

137. Gupta-Elera G, Garrett AR, Robison RA, O'Neill KL. The role of oxidative stress in prostate cancer. Eur J Cancer Prev. 2012;21(2):155-62. https://doi.org/10. 1097/CEJ.0b013e32834a8002.

138. Dayem AA, Choi HY, Kim JH, Cho SG. Role of oxidative stress in stem, cancer, and cancer stem cells. Cancers (Basel). 2010;2(2):859-84. https://doi. org/10.3390/cancers2020859.

139. Rahman I. Oxidative stress, chromatin remodeling and gene transcription in inflammation and chronic lung diseases. J Biochem Mol Biol. 2003;36(1):95-109.

140. Federico A, Morgillo F, Tuccillo C, Ciardiello F, Loguercio C. Chronic inflammation and oxidative stress in human carcinogenesis. Int $\mathrm{J}$ Cancer. 2007;121(11):2381-6. https://doi.org/10.1002/ijc. 23192.
141. Karunakaran U, Park KG. A systematic review of oxidative stress and safety of antioxidants in diabetes: focus on islets and their defense. Diabetes Metab J. 2013;37(2):106-12. https://doi.org/10. 4093/dmj.2013.37.2.106.

142. Chan R, Li S, Choi S, Wang E, Leung J, Benzie I, Sea M, Woo J. Effect of four different meal types on postprandial oxidative stress: a randomized crossover study with healthy subjects. Int J Food Nutr Sci. 2016;3(2):320-30.

143. Ursini F, Zamburlini A, Cazzolato G, Maiorino M, Bon GB, Sevanian A. Postprandial plasma lipid hydroperoxides: a possible link between diet and atherosclerosis. Free Radic Biol Med. 1998;25(2): 250-2.

144. O'Keefe JH, Bell DS. Postprandial hyperglycemia/ hyperlipidemia (postprandial dysmetabolism) is a cardiovascular risk factor. Am J Cardiol. 2007;100(5):899-904. https://doi.org/10.1016/j. amjcard.2007.03.107.

145. Devaraj S, Wang-Polagruto J, Polagruto J, Keen CL, Jialal I. High-fat, energy-dense, fast-food-style breakfast results in an increase in oxidative stress in metabolic syndrome. Metab Clin Exp. 2008;57(6): 867-70. https://doi.org/10.1016/j.metabol.2008.02. 016.

146. Tushuizen ME, Nieuwland R, Scheffer PG, Sturk A, Heine RJ, Diamant M. Two consecutive high-fat meals affect endothelial-dependent vasodilation, oxidative stress and cellular microparticles in healthy men. J Thromb Haemost. 2006;4(5):1003-10. https://doi.org/10.1111/j.1538-7836.2006.01914.x.

147. Newsholme P, Cruzat VF, Keane KN, Carlessi R, de Bittencourt PI, Jr. Molecular mechanisms of ROS production and oxidative stress in diabetes. Biochem J. 2016;473(24):4527-50. https://doi.org/10. 1042/BCJ20160503C.

148. Jiang ZY, Woollard AC, Wolff SP. Hydrogen peroxide production during experimental protein glycation. FEBS Lett. 1990;268(1):69-71.

149. Wolff SP, Dean RT. Glucose autoxidation and protein modification. The potential role of "autoxidative glycosylation" in diabetes. Biochem J. 1987;245(1):243-50.

150. Harding JJ, Beswick HT. The possible contribution of glucose autoxidation to protein modification of diabetes. Biochem J. 1988;249(2):617-8.

151. Halliwell B, Gutteridge JM. Role of free radicals and catalytic metal ions in human disease: an overview. Methods Enzymol. 1990;186:1-85. 
152. Hogg N, Kalyanaraman B, Joseph J, Struck A, Parthasarathy S. Inhibition of low-density lipoprotein oxidation by nitric oxide. Potential role in atherogenesis. FEBS Lett. 1993;334(2):170-4.

153. Rubbo H, Parthasarathy S, Barnes S, Kirk M, Kalyanaraman B, Freeman BA. Nitric oxide inhibition of lipoxygenase-dependent liposome and low-density lipoprotein oxidation: termination of radical chain propagation reactions and formation of nitrogencontaining oxidized lipid derivatives. Arch Biochem Biophys. 1995;324(1):15-25. https://doi.org/10. 1006/abbi.1995.9935.

154. Mizisin AP, Bache M, DiStefano PS, Acheson A, Lindsay RM, Calcutt NA. BDNF attenuates functional and structural disorders in nerves of galactose-fed rats. J Neuropathol Exp Neurol. 1997;56(12):1290-301.

155. Delcroix JD, Michael GJ, Priestley JV, Tomlinson DR, Fernyhough P. Effect of nerve growth factor treatment on p75NTR gene expression in lumbar dorsal root ganglia of streptozocin-induced diabetic rats. Diabetes. 1998;47(11):1779-85.

156. Hounsom L, Horrobin DF, Tritschler H, Corder R, Tomlinson DR. A lipoic acid-gamma linolenic acid conjugate is effective against multiple indices of experimental diabetic neuropathy. Diabetologia. 1998;41(7):839-43. https://doi.org/10.1007/ s001250050996.

157. Stevens MJ, Obrosova I, Cao X, Van Huysen C, Greene DA. Effects of DL-alpha-lipoic acid on peripheral nerve conduction, blood flow, energy metabolism, and oxidative stress in experimental diabetic neuropathy. Diabetes. 2000;49(6):1006-15.

158. Ralevic V, Belai A, Burnstock G. Effects of streptozotocin-diabetes on sympathetic nerve, endothelial and smooth muscle function in the rat mesenteric arterial bed. Eur J Pharmacol. 1995;286(2):193-9.

159. Kamei J, Ohsawa M. Effects of diabetes on methamphetamine-induced place preference in mice. Eur J Pharmacol. 1996;318(2-3):251-6.

160. Mizisin AP, Kalichman MW, Bache M, Dines KC, DiStefano PS. NT-3 attenuates functional and structural disorders in sensory nerves of galactosefed rats. J Neuropathol Exp Neurol. 1998;57(9): 803-13.

161. Kalichman MW, Powell HC, Mizisin AP. Reactive, degenerative, and proliferative Schwann cell responses in experimental galactose and human diabetic neuropathy. Acta Neuropathol. 1998;95(1): 47-56.

162. Fernyhough P, Gallagher A, Averill SA, et al. Aberrant neurofilament phosphorylation in sensory neurons of rats with diabetic neuropathy. Diabetes. 1999;48(4):881-9.

163. Chokroverty S, Seiden D, Navidad P, Cody R. Distal axonopathy in streptozotocin diabetes in rats. Experientia. 1988;44(5):444-6.

164. Chiang $\mathrm{PH}, \mathrm{Wu} \mathrm{SN}$, Tsai EM, et al. Adenosine modulation of neurotransmission in penile erection. Br J Clin Pharmacol. 1994;38(4):357-62.

165. Kawamura M, Heinecke JW, Chait A. Pathophysiological concentrations of glucose promote oxidative modification of low density lipoprotein by a superoxide-dependent pathway. J Clin Investig. 1994;94(2):771-8. https://doi.org/10.1172/ JCI117396.

166. Mittal M, Siddiqui MR, Tran K, Reddy SP, Malik AB. Reactive oxygen species in inflammation and tissue injury. Antioxid Redox Signal. 2017;20(7):1126-67.

167. Gkogkolou P, Bohm M. Advanced glycation end products: Key players in skin aging? Dermatoendocrinol. 2012;4(3):259-70. https://doi.org/10. 4161/derm.22028.

168. Goldin A, Beckman JA, Schmidt AM, Creager MA. Advanced glycation end products: sparking the development of diabetic vascular injury. Circulation. 2006;114(6):597-605. https://doi.org/10. 1161/CIRCULATIONAHA.106.621854.

169. Schmidt AM, Weidman E, Lalla E, et al. Advanced glycation endproducts (AGEs) induce oxidant stress in the gingiva: a potential mechanism underlying accelerated periodontal disease associated with diabetes. J Periodontal Res. 1996;31(7):508-15.

170. Mullarkey CJ, Edelstein D, Brownlee M. Free radical generation by early glycation products: a mechanism for accelerated atherogenesis in diabetes. Biochem Biophys Res Commun. 1990;173(3):932-9.

171. Bayir H, Kagan VE. Bench-to-bedside review: Mitochondrial injury, oxidative stress and apoptosisthere is nothing more practical than a good theory. Crit Care. 2008;12(1):206. https://doi.org/10.1186/ cc6779.

172. Chavakis T, Bierhaus A, Nawroth PP. RAGE (receptor for advanced glycation end products): a central player in the inflammatory response. Microbes Infect. 2004; 6(13):1219-225. doi: https://doi.org/ 10.1016/j.micinf.2004.08.004

173. Fleming TH, Humpert PM, Nawroth PP, Bierhaus A. Reactive metabolites and AGE/RAGE-mediated cellular dysfunction affect the aging process: a minireview. Gerontology. 2011;57(5):435-43. https:// doi.org/10.1159/000322087. 
174. Bierhaus A, Humpert PM, Morcos M, et al. Understanding RAGE, the receptor for advanced glycation end products. J Mol Med (Berl). 2005;83(11): 876-86. https://doi.org/10.1007/s00109-005-06887.

175. Miyata T, Taneda S, Kawai R, et al. Identification of pentosidine as a native structure for advanced glycation end products in beta-2-microglobulin-containing amyloid fibrils in patients with dialysisrelated amyloidosis. Proc Natl Acad Sci USA. 1996;93(6):2353-8.

176. McCarthy AD, Etcheverry SB, Cortizo AM. Effect of advanced glycation endproducts on the secretion of insulin-like growth factor-I and its binding proteins: role in osteoblast development. Acta Diabetol. 2001;38(3):113-22.

177. Baynes JW, Thorpe SR. Role of oxidative stress in diabetic complications: a new perspective on an old paradigm. Diabetes. 1999;48(1):1-9.

178. Baynes JW. Role of oxidative stress in development of complications in diabetes. Diabetes. 1991;40(4): 405-12.

179. Vlassara H. Recent progress in advanced glycation end products and diabetic complications. Diabetes. 1997;46(Suppl 2):S19-25.

180. Wautier JL, Wautier MP, Schmidt AM, et al. Advanced glycation end products (AGEs) on the surface of diabetic erythrocytes bind to the vessel wall via a specific receptor inducing oxidant stress in the vasculature: a link between surface-associated AGEs and diabetic complications. Proc Natl Acad Sci USA. 1994;91(16):7742-6.

181. Thornalley PJ. The enzymatic defence against glycation in health, disease and therapeutics: a symposium to examine the concept. Biochem Soc Trans. 2003;31(Pt 6):1341-2. https://doi.org/10. 1042/bst0311341.

182. Conner JR, Beisswenger PJ, Szwergold BS. Some clues as to the regulation, expression, function, and distribution of fructosamine-3-kinase and fructosamine-3-kinase-related protein. Ann N Y Acad Sci. 2005;1043:824-36. https://doi.org/10.1196/ annals.1333.095.

183. Conner JR, Beisswenger PJ, Szwergold BS. The expression of the genes for fructosamine-3-kinase and fructosamine-3-kinase-related protein appears to be constitutive and unaffected by environmental signals. Biochem Biophys Res Commun. 2004;323(3):932-6. https://doi.org/10.1016/j.bbrc. 2004.08.181.
184. Laight DW, Carrier MJ, Anggard EE. Antioxidants, diabetes and endothelial dysfunction. Cardiovasc Res. 2000;47(3):457-64.

185. Abdel-Wahab MH, Abd-Allah AR. Possible protective effect of melatonin and/or desferrioxamine against streptozotocin-induced hyperglycaemia in mice. Pharmacol Res. 2000;41(5):533-7. https://doi. org/10.1006/phrs.1999.0614.

186. Chow CK. Vitamin E and oxidative stress. Free Radic Biol Med. 1991;11(2):215-32.

187. Asayama K, Hayashibe H, Dobashi K, Niitsu T, Miyao A, Kato K. Antioxidant enzyme status and lipid peroxidation in various tissues of diabetic and starved rats. Diabetes Res. 1989;12(2):85-91.

188. Wallace TC, McBurney M, Fulgoni VL 3rd. Multivitamin/mineral supplement contribution to micronutrient intakes in the United States, 2007-2010. J Am Coll Nutr. 2014;33(2):94-102. https://doi.org/10.1080/07315724.2013.846806.

189. Feairheller DL, Park J-Y, Sturgeon KM, et al. Racial differences in oxidative stress and inflammation: in vitro and in vivo. Clin Transl Sci. 2011;4(1):32-7. https://doi.org/10.1111/j.1752-8062.2011.00264.x.

190. Aggarwal BB, Vijayalekshmi RV, Sung B. Targeting inflammatory pathways for prevention and therapy of cancer: short-term friend, long-term foe. Clin Cancer Res. 2009;15(2):425-30. https://doi.org/10. 1158/1078-0432.CCR-08-0149.

191. Schetter AJ, Heegaard NH, Harris CC. Inflammation and cancer: interweaving microRNA, free radical, cytokine and p53 pathways. Carcinogenesis. 2010;31(1):37-49. https://doi.org/10.1093/carcin/ bgp272.

192. Lin WW, Karin M. A cytokine-mediated link between innate immunity, inflammation, and cancer. J Clin Investig. 2007;117:1175-83.

193. Wautier MP, Chappey O, Corda S, Stern DM, Schmidt AM, Wautier JL. Activation of NADPH oxidase by AGE links oxidant stress to altered gene expression via RAGE. Am J Physiol Endocrinol Metab. 2001;280(5):E685-94. https://doi.org/10.1152/ ajpendo.2001.280.5.E685.

194. Carroll JF, Fulda KG, Chiapa AL, et al. Impact of race/ethnicity on the relationship between visceral fat and inflammatory biomarkers. Obesity. 2009;17(7):1420-7. https://doi.org/10.1038/oby. 2008.657.

195. Martyn CN, Hughes RA. Epidemiology of peripheral neuropathy. J Neurol Neurosurg Psychiatry. 1997;62(4):310-8. https://doi.org/10.1136/jnnp.62. 4.310 . 
196. Nisar MU, Asad A, Waqas A, et al. Association of diabetic neuropathy with duration of type 2 diabetes and glycemic control. Cureus. 2015;7(8):e302. https://doi.org/10.7759/cureus.302.

197. Riddle EL, Fleckenstein AE, Hanson GR. Mechanisms of methamphetamine-induced dopaminergic neurotoxicity. AAPS J. 2006;8(2):E413-8.

198. Vincent AM, Russell JW, Low P, Feldman EL. Oxidative stress in the pathogenesis of diabetic neuropathy. Endocr Rev. 2004;25(4):612-28. https://doi.org/10.1210/er.2003-0019.

199. Feldman EL. Oxidative stress and diabetic neuropathy: a new understanding of an old problem. J Clin Invest. 2003;111(4):431-3. https://doi.org/10. 1172/JCI17862.

200. Gosselin RD, Suter MR, Ji RR, Decosterd I. Glial cells and chronic pain. Neuroscientist. 2010;16(5): 519-31. 1073858409360822 . https://doi.org/10.1177/

201. Dubovy P. Wallerian degeneration and peripheral nerve conditions for both axonal regeneration and neuropathic pain induction. Ann Anat. 2011;193(4):267-75. https://doi.org/10.1016/j. aanat.2011.02.011.

202. Tesch GH. Role of macrophages in complications of type 2 diabetes. Clin Exp Pharmacol Physiol. 2007;34(10):1016-9. https://doi.org/10.1111/j. 1440-1681.2007.04729.x.

203. Jin X, Yao T, Zhou Z, et al. Advanced glycation end products enhance macrophages polarization into M1 phenotype through activating RAGE/NF-kappaB pathway. Biomed Res Int. 2015;2015: 732450. https://doi.org/10.1155/2015/732450.

204. Grosick R, Alvarado-Vazquez PA, Messersmith AR, Romero-Sandoval EA. High glucose induces a priming effect in macrophages and exacerbates the production of pro-inflammatory cytokines after a challenge. J Pain Res. 2018;11:1769-78. https://doi. org/10.2147/JPR.S164493.

205. DiBonaventura MD, Sadosky A, Concialdi K, et al. The prevalence of probable neuropathic pain in the US: results from a multimodal general-population health survey. J Pain Res. 2017;10:2525-38. https:// doi.org/10.2147/JPR.S127014.

206. Koca I, Tutoglu A, Boyaci A, et al. An evaluation of oxidative stress and antioxidant capacity in patients with myofascial pain syndrome. Mod Rheumatol. 2014;24(6):992-6. https://doi.org/10.3109/ 14397595.2014 .886984 .

207. Wasner G, Backonja MM, Baron R. Traumatic neuralgias: complex regional pain syndromes (reflex sympathetic dystrophy and causalgia): clinical characteristics, pathophysiological mechanisms and therapy. Neurol Clin. 1998;16(4):851-68.

208. Borghi SM, Carvalho TT, Staurengo-Ferrari L, et al. Vitexin inhibits inflammatory pain in mice by targeting TRPV1, oxidative stress, and cytokines. J Nat Prod. 2013;76(6):1141-9. https://doi.org/10.1021/ np400222v.

209. Ford TC, Downey LA, Simpson T, McPhee G, Oliver $\mathrm{C}$, Stough C. The effect of a high-dose vitamin b multivitamin supplement on the relationship between brain metabolism and blood biomarkers of oxidative stress: a randomized control trial. Nutrients. 2018. https://doi.org/10.3390/nu10121860.

210. Mauro GL, Martorana U, Cataldo P, Brancato G, Letizia G. Vitamin B12 in low back pain: a randomised, double-blind, placebo-controlled study. Eur Rev Med Pharmacol Sci. 2000;4(3):53-8.

211. Tick H. Nutrition and pain. Phys Med Rehabil Clin N Am. 2015;26(2):309-20. https://doi.org/10.1016/ j.pmr.2014.12.006.

212. Zhao WC, Zhang B, Liao MJ, et al. Curcumin ameliorated diabetic neuropathy partially by inhibition of NADPH oxidase mediating oxidative stress in the spinal cord. Neurosci Lett. 2014;560:81-5. https:// doi.org/10.1016/j.neulet.2013.12.019.

213. Strath LJ, Jones CD, Philip George A, et al. The effect of low-carbohydrate and low-fat diets on pain in individuals with knee osteoarthritis. Pain Med. (in press).

214. Block G, Dresser CM, Hartman AM, Carroll MD. Nutrient sources in the American diet: quantitative data from the NHANES II survey. II. Macronutrients and fats. Am J Epidemiol. 1985;122(1):27-40.

215. Levine $M$, Wang $Y$, Katz A, et al. Ideal vitamin $C$ intake. BioFactors. 2001;15(2-4):71-4.

216. Padayatty SJ, Katz A, Wang Y, et al. Vitamin C as an antioxidant: evaluation of its role in disease prevention. J Am Coll Nutr. 2003;22(1):18-35.

217. Block G. Nutrient sources of provitamin A carotenoids in the American diet. Am J Epidemiol. 1994;139(3):290-3.

218. Murphy SP, Subar AF, Block G. Vitamin E intakes and sources in the United States. Am J Clin Nutr. 1990;52(2):361-7. https://doi.org/10.1093/ajcn/52. 2.361 .

219. Reboul E, Richelle M, Perrot E, Desmoulins-Malezet C, Pirisi V, Borel P. Bioaccessibility of carotenoids and vitamin $\mathrm{E}$ from their main dietary sources. 
J Agric Food Chem. 2006;54(23):8749-55. https:// doi.org/10.1021/jf061818s.

220. Meister A. Biosynthesis and functions of glutathione, an essential biofactor. J Nutr Sci Vitaminol. 1992;38:1-6 (Spec No).

221. Sies H. Glutathione and its role in cellular functions. Free Radic Biol Med. 1999;27(9-10):916-21.

222. Halliwell B. Antioxidants: the basics-what they are and how to evaluate them. Adv Pharmacol. 1997;38:3-20.

223. Clarkson PM, Thompson HS. Antioxidants: what role do they play in physical activity and health? Am J Clin Nutr. 2000;72(2 Suppl):637S-S646. https://doi.org/10.1093/ajcn/72.2.637S.

224. Flohe L. Glutathione peroxidase. Basic Life Sci. 1988;49:663-8.

225. Betteridge DJ. What is oxidative stress? Metab Clin Exp. 2000;49(2 Suppl 1):3-8.

226. Chelikani P, Ramana T, Radhakrishnan TM. Catalase: a repertoire of unusual features. Indian J Clin Biochem IJCB. 2005;20(2):131-5. https://doi.org/ $10.1007 /$ BF02867412.

227. Shay KP, Moreau RF, Smith EJ, Smith AR, Hagen TM. Alpha-lipoic acid as a dietary supplement: molecular mechanisms and therapeutic potential. Biochem Biophys Acta. 2009;1790(10):1149-60. https://doi.org/10.1016/j.bbagen.2009.07.026.

228. Rochette L, Ghibu S, Richard C, Zeller M, Cottin Y, Vergely C. Direct and indirect antioxidant properties of alpha-lipoic acid and therapeutic potential. Mol Nutr Food Res. 2013;57(1):114-25. https://doi. org/10.1002/mnfr.201200608.

229. Rao AV, Rao LG. Carotenoids and human health. Pharmacol Res. 2007;55(3):207-16. https://doi.org/ 10.1016/j.phrs.2007.01.012.

230. Pravst I, Zmitek K, Zmitek J. Coenzyme Q10 contents in foods and fortification strategies. Crit Rev Food Sci Nutr. 2010;50(4):269-80. https://doi.org/ $10.1080 / 10408390902773037$.
231. Cook NC, Samman S. Flavonoids-chemistry, metabolism, cardioprotective effects, and dietary sources. J Nutr Biochem. 1996;7(2):66-76.

232. Kies C. Food sources of dietary copper. Adv Exp Med Biol. 1989;258:1-20.

233. Solomons NW. Dietary sources of zinc and factors affecting its bioavailability. Food Nutr Bull. 2001;22(2):138-54.

234. Black JR, Ammerman CB, Henry PR, Miles RD. Biological availability of manganese sources and effects of high dietary manganese on tissue mineral composition of broiler-type chicks. Poult Sci. 1984;63(10):1999-2006. https://doi.org/10.3382/ps. 0631999.

235. Rayman MP. Selenium and human health. Lancet. 2012;379(9822):1256-68. https://doi.org/10.1016/ S0140-6736(11)61452-9.

236. Dietrich M, Brown CJ, Block G. The effect of folate fortification of cereal-grain products on blood folate status, dietary folate intake, and dietary folate sources among adult non-supplement users in the United States. J Am Coll Nutr. 2005;24(4):266-74.

237. Looman M, van den Berg C, Geelen A, et al. supplement use and dietary sources of folate, vitamin $\mathrm{D}$, and $\mathrm{n}-3$ fatty acids during preconception: the GLIMP2 Study. Nutrients. 2018. https://doi.org/10. 3390/nu10080962.

238. Scott JM. Folate and vitamin B12. Proc Nutr Soc. 1999;58(2):441-8.

239. Banjari I, Hjartaker A. Dietary sources of iron and vitamin B12: Is this the missing link in colorectal carcinogenesis? Med Hypotheses. 2018;116:105-10. https://doi.org/10.1016/j.mehy.2018.05.003.

240. Mielgo-Ayuso J, Aparicio-Ugarriza R, Olza J, et al. Dietary intake and food sources of niacin, riboflavin, thiamin and vitamin $\mathrm{B}(6)$ in a representative sample of the Spanish Population. The Anthropometry, Intake, and Energy Balance in Spain (ANIBES) Study dagger. Nutrients. 2018. https://doi. org/10.3390/nu10070846. 